Regarding the folk tale Dorothy Stephens remarks: "Signs in the House of Busyrane caution Britomart, 'Be bold, be bold,' and then 'Be not too bold' (III.xi.54), quotations from the Bluebeard folk tale. In the Bluebeard text behind Spenser's text, the next sentence of the jingle is 'Lest that your heart's blood should run cold.' Because in the folk tale Mr. Fox (Bluebeard) commands Lady Mary not to look at his former wives, intending to make her join them if she does, Busyrane's own allusion to the tale implicitly warns his headstrong guest that it could be lethal for her to attempt any sort of meeting with the woman who is his prisoner." See Stephens, The Limits of Eroticism in Post-Petrarchan Narrative (Cambridge: Cambridge University Press, 1998), 32. Shakespeare also alluded to this tale in Much Ado About Nothing. For further analysis of this folk tradition, see K. M. Briggs's discussion of "The Hole the Fox Did Make," an offshoot of the international tale type The Robber Bridegroom in "Historical Traditions in English Folk-Tales," Folklore 75 (1964), 235-240. Briggs prints one of the more memorable versions of this tale, centrally relying on the "be . . . be . . be not too bold" pattern in A Dictionary of British Folk-Tales in the English Language (London: Routledge \& Kegan Paul, 1970), 1:446-448. For further contextual discussion, see Jacqueline Simpson, “'Be Bold, but not Too Bold': Female Courage in Some British and Scandinavian Legends," Folklore 102 (1991), 19-20.

7 Whitman, Notebooks and Unpublished Prose Manuscripts, ed. Edward Grier (New York: New York University Press, 1984), 5:1884. Ed Folsom discusses this passage in "Trying to do Fair: Walt Whitman and the Good Life," Speakeasy 10 (March/April 2004), 17.

8 Thanks go to Ed Folsom for drawing my attention to this passage and for his comments on it.

\title{
AN UNRECORDED WHITMAN INTERVIEW
}

In the New York Tribune of May 19, 1890, there appeared an article entitled "Whitman Near the End," in which an anonymous correspondent reports on his trip to Whitman's Mickle Street home in Camden, New Jersey, where he talked with Mary Davis, Whitman's housekeeper, as well as with Whitman himself. The article is accompanied by an engraved portrait of Whitman, an engraving of his Mickle Street home, and a facsimile of his signature. A copy of the article was tucked into one of the copies of the 1881-1882 Leaves of Grass (Boston: James R. Osgood) owned by Whitman collector Kendall Reed. Previously unrecorded, this interview offers some illuminating details of Whitman's last years, including an intriguing explanation of why he never married. Here is the entire article:

\section{WHITMAN NEAR THE END}

Pitiful Life of the Good Gray Poet at Camden 
There Isn't Anything to Make Life Worth the Living Now-Surroundings of this Man Who Has Worked and Suffered Much-Quietly Waiting for Death-Interesting Account of a Recent Visit to His Home

It is not given to many men to preserve through unvarying seasons of popular misapprehension the optimistic temperament and faith in his kind that characterize Walt Whitman. Unduly abused by the many, extravagantly praised by the few, he has neither drawn tighter his cloak to protect him from the storm, nor cast it aside because of the noonday sun's fierce heat, but has walked forward undismayed along his appointed course, praising humanity, glorifying America, confident in the future of his race, says the New York Press. As a result he has two constant friends. They are:

A woman and a dog.

I hope never again to experience such shock as I did the other afternoon on reaching No. 328 Mickle street, Camden. I had read of Walt Whitman's “comfortable but modest home," and was unprepared for the reality. Only on the testimony of two witnesses - a passer-by and the door plate - could I bring myself to believe that this was the house of the "good gray poet." It needs paint on its weather-beaten boards, it needs new blinds at the dingy windows, but, more than all, it needs condemnation and destruction at the hands of the city authorities. The door was opened in response to my ring by a gentle-faced, wistful-eyed, elderly woman.

"Please step into the parlor," she said, "while I take your card to Mr. Whitman. His health is precarious now."

A spotted coach dog sniffed suspiciously about me.

"Don't mind Homer," she added; "he's harmless, and Mr. Whitman's favorite companion. Why? Because he doesn't bother him with silly questions, I think."

In response to the announcement I climbed a narrow stairway to an upper room. I went directly to one object of my mission and told him that an admirer was anxious to furnish him easy employment of a congenial nature. The fine pink skin flushed, the eloquent gray blue eyes lost a little of their luster.

"Tell Mr. -," he said, "that Walt Whitman thanks him. These are all bad days now, but when they are only half bad I like to scribble yet. This offer means" - a pause- "it means that I shall be glad to do the work if I can."

Was there not another meaning also to that broken sentence? I thought so as I looked at the great table piled high with books and papers, at the hard bed and uninviting lounge, at the windows through which no waving tree or nodding flower smiled welcome to their lifelong friend, at the man himself, royal and self-respecting, a diamond set in dross, but shining with greater brilliance because of the mean surroundings.

We talked of "Leaves of Grass," the book which secured Whitman's discharge from the Interior Department by Secretary Harlan and gained him the friendship of Tennyson and of the days when its author nursed the soldier boys. "I never married," he said, "for in place of a bride nature gave me sufferers to care for and scenes to clothe with poetry. Here," he continued, changing the subject, "is my message to the young authors: 'Employ not evil for its own sake. Make it a foil for purity."'

I told him of passages in his writings which I admired and referred particularly to "My Captain," that eloquent lament that marks the martyrdom of Lincoln like a monument. I quoted:

Exult, $\mathrm{O}$ shores, and ring, $\mathrm{O}$ bells;

But I, with mournful tread,

Walk the deck; my captain lies

Fallen cold and dead.

"I'm glad you fancy that," he said quietly. "I thank you for your appreciation." 
Not a word of self praise; not a syllable of self depreciation; a simple proud humility in the acknowledgment of pleasure that his printed thoughts were remembered by a stranger.

I had outstaid the moments to which I was pledged to limit my visit. I rose to go, and our hands met in friendly farewell. "Stay," he exclaimed. "Do you care for this?" and he wrote with firm stroke the following:

\section{Walt Whitman}

April 22 '90

Then he added his message of regard to "the boys in New York," and we parted.

At the foot of the stairs stood the two faithful watchers. The dog bounded up the steps; with the woman I stopped to chat a moment. "You did right," she smiled sadly, "not to bother him with questions. He is over 70 now, and the years bring their weight."

Outside the sun shone, the birds sang, and the boys played. Within the doors sat the uncomplaining patriarch who has chanted the might and glory of America, and yet, strange to say, has gained greater applause and more practical sympathy beyond the seas than from the land he has celebrated.

Whitman does not explicitly mention this visit to Horace Traubel in With Walt Whitman in Camden, but on the evening of April 22, 1890, he does refer to the "easy employment of a congenial nature" that seemed to be the main purpose of the correspondent's visit. Whitman tells Traubel:

Today I had an application from the American Press Association. What for? A specialty? Oh no! - anything, I suppose-prose or verse. $\mathrm{O}$ the mutations of years! Only a few years ago - five only-I waited for just such orders - wondered, and was willing, able, still with a modicum of strength: but no message came-the world did not want me. Now - hardly half a decade after, comes a multitude: comes cry and cry-after my power to respond is gone: after I am wrecked, stranded, left but to look for the end - or near end! And yet there is a sense of satisfaction in this. . .." (WWC 6:373-374).

In his Daybook for April 22, 1890, Whitman noted that he was receiving "quite a number of offers f'm publishers, magazine editors, \& heads of newspaper syndicates these times" ( $D B N$ 2:551). So, even though Whitman had been "too ill" to see his friend John Forney's daughter, who stopped by that day for a visit (WWC 6:374), he clearly had signaled Mary Davis to allow the Tribune correspondent to come up to his room so that he could collect another welcome offer to publish his work.

The University of Iowa

ED FoLSOM

\section{HUNEKER'S “A VISIT TO WALT WHITMAN”}

I have dealt previously with James Gibbons Huneker's connection with and criticism of Walt Whitman. ${ }^{1}$ Here I want to focus on Huneker's most extensive discussion of Whitman, his essay "A Visit to Walt Whitman," which was briefly foreshadowed in his "Raconteur" column in the Musical Courier 37 (July 12, 1898), 23-24; elaborated to essay length in his "The Seven Arts" column in Puck 76 (November 21, 1914), 8, 20; and reprinted in his book Ivory Apes and Peacocks (New York: Charles Scribner's Sons, 1915), 22-31 (hereafter $I A P$ ). 